\title{
Hepatitis C Virus Genotypes in Blood Donors from the Federal District, Central Brazil
}

\author{
Regina MS Amorim/ ${ }^{++}$, Claudiner P O liveira/ ${ }^{++}$, Patrícia S Wyant/ ${ }^{++}$, \\ Daniela M Cerqueira/ ${ }^{++}$, Geni NL Câmara*, Luciano S Flores**, Regina MB Martins***, \\ Cláudia RF Martins ${ }^{+}$
}

\begin{abstract}
Departamento de Biologia Celular, Instituto de Biologia, Universidade de Brasília, ICC Sul, 70919-900 Brasília, DF, Brasil
*Agência Nacional de Vigilância Sanitária, Brasília, DF, Brasil **Hemocentro de Brasília, Brasília, DF, Brasil ***Universidade

Federal de Góias, Goiânia, GO, Brasil
\end{abstract}

The objective of this study was to characterize hepatitis C virus (HCV) genotypes in blood donors from the Federal District, Central Brazil, and to compare HCV screening by serological assays and reverse transcriptase polymerase chain reaction (RT-PCR). Plasma samples from 57 individuals with reactive or indeterminate results in serological anti-HCV screening assays (ELISA or EIA) were tested for HCV RNA by RT-PCR. The results from a confirmatory LIA serological assay were also evaluated. The 5' non-coding region of the HCV genome was amplified from 41 PCR positive samples (71.9\%), which were further characterized by nucleotide sequencing analysis. Of these, $60.9 \%$ were of HCV genotype 1 and $39.1 \%$ of genotype 3.

Key words: hepatitis C virus - genotypes - Federal District, Central Brazil

Hepatitis C Virus (HCV) has been classified into six major genotypes and several subtypes, which may produce clinically relevant differences in the response to interferon therapy. Infection with genotype 1 is associated with a poorer response to interferon treatment when compared to infection with other genotypes (Zein 2000).

Genotypes 1, 2, and 3 have a worldwide distribution. Genotype 4 is more prevalent in North Africa and in the Middle East, while genotypes 5 and 6 occur more commonly in South Africa and Asia, respectively (Zein 2000). In Brazil, several studies have shown that genotype 1 is the most prevalent one, followed by genotype 3 (Bassit et al. 1994, Krug et al. 1996, Martins et al. 1998).

Molecular and serological detections of HCV play an important role in the diagnosis of infection, therapeutic decision-making, and assessment of the virologic response to therapy. In addition, it might reduce the frequency of post-transfusion hepatitis (Smith et al. 1995, Zein 2000, Pawlotsky 2002).

The purpose of the present study was to characterize $\mathrm{HCV}$ genotypes in volunteer blood donors from the Federal District (Central Brazil) and to compare the results of routine serological assays with those obtained by HCV reverse transcriptase polymerase chain reaction (RT-PCR).

Financial support: Conselho Nacional de Desenvolvimento Científico e Tecnológico (CNPq), Fundação de Empreendimentos Científicos e Tecnológicos

${ }^{+}$Corresponding author. Fax: +55-61-272.1793. E-mail: cmartins@unb.br

${ }^{++}$Fellowship from $\mathrm{CNPq}$

Received 24 May 2004

Accepted 19 November 2004
Plasma samples from 57 voluntary blood donors were obtained between March 2001 and June 2002 at two blood banks located at the Federal District: the Hemocentro and the Hemoclínica of the Santa Lúcia Hospital. The Committee on Research Ethics from the University of Brasília granted prior approval to this research project.

Serum samples were previously screened using routine HCV enzyme immunoassays (ELISA - Ortho Diagnostics Systems or EIA - Abbott Prism HCV). The results of these anti-HCV assays were expressed as the optical densities (OD) of the samples divided by the cut off value (C). Samples with ratio OD/C $<0.9$ were considered nonreactive, and those with ratio $\mathrm{OD} / \mathrm{C}>0.9$ and $<1.1$ were classified as indeterminate. Samples with ratio OD/C $>1$ and $<3$ were reactive and those with $\mathrm{OD} / \mathrm{C}>3$ were highly reactive. All 57 samples were retested by a supplementary line immunoblot assay (Lia Tek HCV III, Organon-Teknika). All tests were performed according to the manufacturer's instructions.

The 57 samples, all classified as reactive or indeterminate by ELISA, were subjected to RNA extraction using the QIAmp Viral RNA Kit (Qiagen), according to the manufacturer's protocol. Complementary DNA (cDNA) was synthesized from $2 \mu 1$ of extracted RNA using $200 \mathrm{U}$ of $M-M u L V$ RT (Gibco-BRL) plus $0.2 \mathrm{mM}$ each dNTP (Gibco-BRL), 2 U RNAse inhibitor (Pharmacia Biotech), and $0.5 \mu \mathrm{g}$ of random primer. The reaction condition was $42^{\circ} \mathrm{C}$ for $90 \mathrm{~min}$. The cDNA was used as a template in a nested PCR amplification by using two primer sets matching a conserved region in the 5' UTR of the different HCV genotypes (Ginabreda et al. 1997). One microliter of the resulting cDNA was used in outer PCR amplification, in a total volume of $50 \mu \mathrm{l}$ over 35 cycles, each consisting of $15 \mathrm{~s}$ at $94^{\circ} \mathrm{C}, 45 \mathrm{~s}$ at $50^{\circ} \mathrm{C}$ and $1 \mathrm{~min}$ at $72^{\circ} \mathrm{C}$. A final step $(7$ min at $72^{\circ} \mathrm{C}$ ) was included after the last cycle. The solu- 
tion was adjusted to a final concentration of $0.25 \mathrm{mM}$ each dNTP (Gibco-BRL), 1x Taq buffer (Gibco-BRL), 20 $\mathrm{nM}$ of each primer, and $2 \mathrm{U}$ Taq polymerase (Gibco-BRL). From the first round of amplification, $1 \mu \mathrm{l}$ was re-amplified with the nested primers in the same conditions. For each PCR assay, water and an anti-HCV negative sample were used as negative controls. The amplification gave a 253bp product from HCV RNA positive samples.

Nested PCR products were sequenced automatically by the dideoxynucleotide chain termination method, in a Megabace System (Amersham-Pharmacia). The homology among HCV sequences from the Federal District and those already deposited at GenBank was analyzed using the BLAST program (available at http://www.ncbi.nih. nlm.gov).

A data bank was generated and analyzed in EPI-Info, 6.04d, from the Center of Diseases Control and Prevention (CDC). The level of significance of tests (p) was set at 0.05 .

The median age of the 57 blood donors included in our study was 33.5 , ranging from 18 to 57 years old. The majority of them were men (78\%) and first-time donors $(82 \%)$. Twenty-two individuals (38.6\%) reported risk factors possibly associated to $\mathrm{HCV}$ transmission: intravenous drug use $(40.9 \%)$, surgery $(36.4 \%)$, blood transfusion $(9.1 \%)$, and sexually or parentally transmitted diseases $(4.5 \%)$.

HCV RNA positivity was found in 41 samples (71.9\%). At a previous study in Central Brazil, Martins et al. (1994) found a similar frequency (76.6\%) of HCV viremia in anti$\mathrm{HCV}$ positive blood donors. These PCR positive samples were genotyped by nucleotide sequences similarity analysis using BLAST. The frequency of genotype 1 was $60.9 \%$ and that of genotype 3 was $39.1 \%$. The 41 PCR positive samples were subtyped as $1 \mathrm{a}(34.1 \%), 1 \mathrm{~b}(26.8 \%)$, and $3 \mathrm{a}$ $(39.1 \%)$.

In the supplementary immunoblot assay, $50.8 \%(\mathrm{n}=$ 29) were reactive, $17.6 \%(\mathrm{n}=10)$ had an indeterminate result, and $31.6 \%(n=18)$ were non-reactive. Of the 41 PCR positive samples, $65.8 \%(\mathrm{n}=27)$ had a reactive, $17.1 \%$ $(\mathrm{n}=7)$ an indeterminate, and $17.1 \%(\mathrm{n}=7)$ a non-reactive result on the immunoblot supplementary assay. For the 16 samples with a negative result on PCR, 68.75\% were also negative, $18.75 \%$ were indeterminate, and $12.50 \%$ were positive on immunoblot assay. The correlation between $\mathrm{HCV}$ viremia and positivity by serological assays is shown in the Table.

Due to the fact that some authors previously reported a relation between anti HCV ratio $>3$ and detectable HCVRNA by RT nested PCR (Gretch et al. 1992, Gonçalves et al. 2000), the 57 samples initially classified as reactive or indeterminate on the anti-HCV serological assay were further divided into two groups: $56.1 \%(\mathrm{n}=32)$ had ratio OD/ $C>3$ and $43.9 \%(n=25)<3$. Among the 32 samples with OD/C > 3, 93.7\% ( $\mathrm{n}=30)$ were positive for HCV RNA by PCR, whereas the 25 with OD/C $<3$ only $44 \%(n=11)$ were PCR positive. No correlation between anti HCV reactive, PCR positive samples and ALT levels was observed $(\mathrm{p}=$ 0.40 ) and only four individuals showed elevated levels of transaminases.
TABLE

Results of the reverse transcriptase nested polymerase chain reaction (PCR) for hepatitis $\mathrm{C}$ virus (HCV) RNA, anti-HCV enzyme-linked immunosorbent assay (ELISA) and immunoblot serological assays

\begin{tabular}{lll}
\hline ELISA & \multicolumn{2}{c}{ Immunoblot positive $(\mathrm{n}=29)$} \\
\hline & PCR positive & PCR negative \\
$\mathrm{OD} / \mathrm{C}>3$ & $27 / 29(93.1 \%)$ & $2 / 29(6.9 \%)$ \\
$\mathrm{OD} / \mathrm{C}<3$ & $0 / 29$ & $0 / 29$ \\
\hline \multicolumn{4}{c}{ Immunoblot indeterminate $(\mathrm{n}=10)$} \\
\hline & PCR positive & PCR negative \\
$\mathrm{OD} / \mathrm{C}>3$ & $1 / 10(10 \%)$ & $0 / 10$ \\
$\mathrm{OD} / \mathrm{C}<3$ & $6 / 10(60 \%)$ & $3 / 10(30 \%)$ \\
\hline & \multicolumn{4}{c}{ Immunoblot negative $(\mathrm{n}=18)$} \\
\hline & PCR positive & PCR negative \\
OD/C $>3$ & $2 / 18(11 \%)$ & $0 / 18$ \\
OD $/ \mathrm{C}<3$ & $5 / 18(27.8 \%)$ & $11 / 18$ \\
$(61.2 \%)$ & &
\end{tabular}

OD/C: optical density divided by the cut off value.

Nowadays, the prevention of transfusion-associated hepatitis $\mathrm{C}$ in Brazil relies on the screening of blood samples and the prevalence of anti-HCV reactive samples among blood donors in Brazil was 0.52\% in 2001 and $0.48 \%$ in 2002 (http://www.anvisa.gov.br). Nevertheless, PCR may improve the reliability of $\mathrm{HCV}$ diagnosis and is very sensitive and specific in detecting viremia and therefore potentially infectious blood donors (Sönmez et al. 1996, Ginabreda et al. 1997, Gonçales et al. 2000). We found a correlation between the presence of serum HCV RNA and anti-HCV positivity $(\mathrm{p}<0.05)$. However, among individuals with the ratio OD/C $<3$ on ELISA and classified as indeterminate or negative by the supplementary immunoblot assay, HCV RNA was identified in $44 \%$ of the sample. Immunoblot indeterminate results were generally (70\%) associated with PCR positivity, indicating the need to screen these donors for HCV-RNA in peripheral blood. These results suggest that anti-HCV assays are not sensitive enough to screen all asymptomatic HCV carriers.

Two samples (3.5\%) had a high OD/C ratio on ELISA (>3) and a positive result on the supplementary immunoblot, but were negative for HCV RNA. This may reflect very low levels of viremia or virus clearance, since a proportion of individuals varying from 15 to $25 \%$ do not progress to chronic infection (Hoofnagle 2002).

Routine immunoassays, such as ELISA, proved to be valuable in identifying potentially infectious donors capable of transmitting hepatitis $\mathrm{C}$, mainly in individuals with $\mathrm{OD} / \mathrm{C}$ ratios $>3$. We observed that, in most cases (93.7\%), this high anti-HCV ratio was associated with HCVRNA positivity by PCR. However, the screening of lowrisk populations such as blood donors can give a substantial number of anti-HCV false-positive results, mainly when low ELISA optical densities are obtained (Martins et al. 1994). We observed that $24.6 \%$ of the sera with OD/ $\mathrm{C}<3$ were negative by RT-PCR. 
Genotyping of HCV isolates has been shown to be of clinical importance. Nucleotide sequencing analysis of a selected part of the viral genome has been used to determine the genotype of HCV isolates (Ginabreda et al. 1997). To limit the occurrence of false-negatives in the PCR assay, we used primers in the 5'UTR of the HCV genome, which is over $98 \%$ conserved among different isolates (Ginabreda et al. 1997). The usage of the 5'UTR sequencing for $\mathrm{HCV}$ subtyping is considered controversial, since this is a very conserved region of the genome (Pawlotsky 2002). Generally, only genotypes are used for clinical decision related to therapy as different subtypes from the same genotype have few clinical consequences (Krug et al. 1996, Pawlotsky 2002).

The highest prevalence of HCV genotype 1 (60.9\%), followed by genotype 3 (39.1\%) in the Federal District corroborates previous data from Brazil. In Bahia, Northeastern Brazil, HCV genotype 1 is the most frequent one (66.1\%), followed by the genotype $3(33.9 \%)$. In the Southeast Region, genotype 1 is also predominant (55\%), followed by genotypes $3(37 \%)$, and $2(8 \%)$ (Bassit et al. 1994, Krug et al. 1996, Martins et al. 1998, Busek \& Oliveira 2003, Codes et al. 2003).

\section{ACKNOWLEDGEMENTS}

To John Penney, for reviewing this manuscript.

\section{REFERENCES}

Bassit L, Vanderborght B, Dorlhiac-Llacer PE, Chamone DAF, Alquezar AS 1994. Anti-HCV cPCR positivity and HCV subtypes among screening positive blood donors from São Paulo. Rev Soc Bras Med Trop 27 (Sup. 1): 98.

Busek S, Oliveira G 2003. Molecular epidemiology of the hepatitis C virus in Brazil. Genet Mol Res 2: 117-123.

Codes L, de Freitas LA, Santos-Jesus R, Vivitski L, Silva LK, Trepo C, Reis MG, Parana R 2003. Comparative study of hepatitis $\mathrm{C}$ virus genotypes 1 and 3 in Salvador, Bahia,
Brazil. Braz J Infect Dis 7: 409-417.

Ginabreda MGP, Yoshida CFT, Niel C 1997. Genomic characterization of Brazilian hepatitis $\mathrm{C}$ virus genotypes 1a and 1b. Braz J Med Biol Res 30: 339-345.

Gonçales NSL, Costa FF, Vassallo Jr J, Gonçales FL 2000. Diagnosis of hepatitis $\mathrm{C}$ virus in Brazilian blood donors using a reverse transcriptase nested polymerase chain reaction: comparison with enzyme immunoassay and recombinant immunoblot assay. Rev Inst Med Trop São Paulo 42: 263-267.

Gretch D, Lee W, Corey L 1992. Use of aminotransferase, hepatitis $\mathrm{C}$ antybody, and hepatitis $\mathrm{C}$ polymerase chain reaction RNA assays to establish the diagnosis of hepatitis $\mathrm{C}$ virus infection in the diagnostic virology laboratory. J Clin Microbiol 30: 2145-2149.

Hoofnagle JH 2002. Course and outcome of hepatitis C. Hepatology 36 (Suppl.): S21-S29.

Krug LP, Lunge VR, Ikuta N, Fonseca AS, Cheinquer H, Ozaki LS, Barros SG 1996. Hepatitis C virus genotypes in Southern Brazil. Braz J Med Biol Res 29: 1629-1632.

Martins RM, Vanderborght BO, Rouzere CD, Santana CL, Santos CO, Mori DN, Ferreira RG, Yoshida CF 1994. Anti$\mathrm{HCV}$ related to HCV PCR and risk factors analysis in a blood donor population of central Brazil. Rev Inst Med Trop São Paulo 36: 501-506.

Martins RMB, Vanderborght BO, Yoshida CFT 1998. Hepatitis $\mathrm{C}$ virus genotypes among blood donors from different regions of Brazil. Mem Inst Oswaldo Cruz 93: 299-300.

Pawlotsky JM 2002. Molecular diagnosis of viral hepatitis. Gastroenterology 122: 1554-1568.

Smith DB, Mellor J, Jarvis LM, Davidson F, Kolberg J, Urdea M, Yap P-L, Simmonds P, The International HCV Collaborative Study Group 1995. Variation of the hepatitis C virus 5' non-coding region: implications for secondary structure, virus detection and typing. J Gen Virol 76: 1749-1761.

Sönnez E, Troisi C, Hollinger BF, Lin JH, Naem M 1996. Screening of blood donors for HCV RNA by RT-PCR. J Turgut Özal Med Center 3: 303-305.

Zein NN 2000. Clinical significance of hepatitis C virus genotypes. Clin Microbiol Rev 13: 223-235. 
